\title{
Holocene Climate Evolution of the Ugii Nuur Basin, Mongolia
}

\author{
Wolfgang SCHWANGHART*1, Brigitta SCHÜTT ${ }^{2}$, and Michael WALTHER ${ }^{3}$ \\ ${ }^{1}$ Department of Environmental Sciences, University of Basel, Basel, Switzerland \\ ${ }^{2}$ Institute of Geographical Sciences, Freie Universität Berlin, Berlin, Germany \\ ${ }^{3}$ Mongolian Landscape Research Centre, National University of Mongolia, Ulaanbataar, Mongolia
}

(Received 16 May 2007; revised 29 February 2008)

\begin{abstract}
In order to evaluate the Holocene palaeoenvironmental evolution of the Ugii Nuur basin, central Mongolia, investigations on chemical and mineralogical properties of lacustrine sediments were carried out on a 630 $\mathrm{cm}$ sediment core from lake Ugii Nuur. The interpretation of the record is based on a principal component analysis (PCA) of the elemental composition of the samples. The results show that lacustrine deposition started at 10.6 kyr BP. Low lake level conditions were identified during the Early Holocene (10.6-7.9 kyr BP). The Mid Holocene (7.9-4.2 kyr BP) was characterized by generally higher lake levels and thus higher moisture supply, but it experienced strong climatic fluctuations. Arid conditions prevailed from 4.2-2.8 kyr $\mathrm{BP}$ and were followed by a stable, more humid phase until today.
\end{abstract}

Key words: lake sediments, palaeoclimate, Central Asia, Mongolia, Holocene

Citation: Schwanghart, W., B. Schütt, and M. Walther, 2008: Holocene climate evolution of the Ugii Nuur basin, Mongolia. Adv. Atmos. Sci., 25(6), 986-998, doi: 10.1007/s00376-008-0986-4.

\section{Introduction}

Moisture availability is one of the most important natural factors governing almost all aspects of societal and economical life. In East and Central Asia, moisture supply is mainly attributed to the Indian and South-East Asian Monsoon. These wind systems are highly variable in space and time driven by interactions between the global atmosphere, oceans, land and ice systems as well as conditions imposed by the concurrence of the East Asian land mass and solar radiation (An et al., 2000).

A key to the understanding of the complex controls on these wind systems are records of climate change that are accessed and interpreted by palaeoenvironmental research. A large number of studies on the Chinese loess sequences (e.g., Maher and Thomson, 1991; Madsen et al., 1998; Fang et al., 1999; Zhu et al., 2004; Liu et al., 2005), lake systems (e.g., Walther et al., 2003; Wünnemann et al., 2005; Prokopenko et al., 2007), ice cores (e.g., Thompson et al., 1997; Yao et al., 1997) and speleothems (e.g., Wang et al., 2001) have provided insight into the climatic and environ- mental evolution of the regions affected by monsoon variability and, thus, increased the understanding of their sensitivity to climatic change.

Moreover, current research on the human dimension of monsoon variability increased the understanding of climate and human interactions in monsoonal Asia (Rost et al., 2003; An et al., 2005; Fu and de Vries, 2006; Yancheva et al., 2007). This issue becomes particularly challenging when considering the environmental changes and problems that monsoonal Asia faces, especially in its arid and semi-arid regions which are likely to increase in the future driven by climate change (Liu and Diamond, 2005).

An understanding of the prehistorical and historical climate and human interactions in central Mongolia is the aim of ongoing research conducted by archaeologists from University of Bonn (Germany) and geographers from Freie Universität Berlin (Germany). Their research focuses on the Orkhon Valley which has experienced a vicissitudinous history of human influence (Rösch et al., 2005) since various cultures preferred this region as a settlement location due to its strategic position (Bemmann et al., 2008). Moreover, its situa-

\footnotetext{
*Corresponding author: Wolfgang SCHWANGHART, w.schwanghart@unibas.ch
} 
tion in the semi-arid steppe region makes it highly vulnerable to climate change (Gunin et al., 1999; Tarasov et al., 1999; Dulamsuren et al., 2005).

Since the climatic forces, their variability, and the environmental history of this region are still poorly understood, this paper addresses the paleoenvironmental history of the Ugii Nuur basin in the Orkhon Valley during the Holocene. We accomplish this goal by analyzing a lake sediment core spanning the entire Holocene history of Lake Ugii Nuur. The interpretation is based on chemical and mineralogical properties of the lake sediments.

\section{Regional setting}

Lake Ugii Nuur is located at $47^{\circ} 44^{\prime} \mathrm{N}$ and $102^{\circ} 46^{\prime} \mathrm{E}$ at an elevation of $1328 \mathrm{~m}$ EGM96 (see Fig. 1). The freshwater lake has a surface area of ca. $26 \mathrm{~km}$ and a maximum depth of $16 \mathrm{~m}$. Presently, the lake is described as a thermally stratified, oligo- to mesotrophic, dimictic lake with a visible depth of $7.3 \mathrm{~m}$. The metalimnion is found between 10 and $12 \mathrm{~m}$ above an unstable hypolimnion (Völker, 2005). The lake basin opens towards the $12-20 \mathrm{~km}$ wide Orkhon valley in the western part of the catchment. The Old Orkhon River (Chögschin Gol) constitutes the inlet in the western part of the lake. This perennial river drains an area of $4655 \mathrm{~km}$ that includes the eastern branches of the Khangay Mountains. The outlet is located northwest of the inlet and joins the Orkhon River after a distance of $7 \mathrm{~km}$ (Fig. 1). This water course is only ephemerally active due to overflow from Ugii Nuur. During the two field campaigns in summer 2005 and 2006 it was dried out or marshy.

While terrain in the southern and eastern drainage basin is characterized by undulating relief, the northern part is hilly to mountainous with elevations up to $1600 \mathrm{~m}$. Bedrock in the basin consists to a large extent of aeolian silts and fine sands covering Carboniferous shists and shales that outcrop along ridges and steep slopes (Schwanghart and Schütt, 2008). Cliff lines along the southern and eastern shore are partly composed of conglomerates of probably late Cretacious and Tertiary age (Traynor and Sladen, 1995; Sladen and Traynor, 2000). Soils are weakly developed and differentiated by Leptosols, Regosols and Kastanozems according to their position in the relief (Haase, 1983).

The Ugii Nuur basin is characterized by an extremely continental climate. Kharkhorin, a town located about $60 \mathrm{~km}$ south of Lake Ugii Nuur (Fig. 1), has a mean annual air temperature around zero and a yearly precipitation amount of approx. $290 \mathrm{~mm}$ (196283). The continentality causes a strong seasonality in temperature and precipitation. Mean January air tem- peratures of $-18.2^{\circ} \mathrm{C}$ contrast mean July air temperatures of $16.8^{\circ} \mathrm{C}$. Highest precipitation rates generated by heavy rainfalls are found in summer, while precipitation in winter (November to March) occurs mostly in solid form and rarely exceeds $10 \mathrm{~mm}$ per month. The study site is situated within the area of dry, grass steppes (Hilbig, 1995; Opp and Hilbig, 2003) and is dominated by grasses (Cleistogenes, Stipa), forbs (Allium), and shrubs (Artemisia, Caragana) while trees are generally lacking.

\section{Methods}

\subsection{Sediment extraction and analysis}

The sediment core Ugi-4 was drilled at the deepest point of Ugii Nuur in 2003 using a Usinger piston corer. The core has a length of $630 \mathrm{~cm}$ and was sampled with an interval of $10 \mathrm{~cm}$ and a resolution of 2 $\mathrm{cm}$. Prior to chemical and mineralogical analysis, the samples were dried at $50^{\circ} \mathrm{C}$, screened of components larger $2 \mathrm{~mm}$ and homogenized in an agate disk swing mill (Lieb-Technik). We used a conductrometric carbon analyzer (Wöesthoff, detection limit $=0.02$ mass- $\%$ C) to determine the total and inorganic carbon (TIC) content. Total organic carbon (TOC) content was calculated as the difference of both values. Mineralogical compounds were analyzed by $X$-ray powder diffraction using a copper $k_{\alpha}$-tube (PW1729/40, Phillips) from $2 \theta=2^{\circ}-52^{\circ}$ and a step width of $2 \theta=0.01^{\circ}$ with each step measured for one minute. Contents of mineral components were recorded semi-quantitatively (vol.\%) using the software package Phillips X'Pert Highscorev 1.0b (PW3209). After preparing samples using aqua regia and microwave digestion, we analyzed the element composition ( $\mathrm{Ca}, \mathrm{Cr}, \mathrm{Cu}, \mathrm{Fe}, \mathrm{K}, \mathrm{Mg}$, $\mathrm{Mn}, \mathrm{Na}, \mathrm{Ni}, \mathrm{Pb}, \mathrm{PO}_{4}, \mathrm{~S}, \mathrm{Sr}$ ) by inductively coupled plasma atomic emission spectroscopy (ICP-AES, Optima 3000, Perkin Elmer).

\subsection{Age control}

Age control was established by atomic mass spectrometer (AMS) ${ }^{14} \mathrm{C}$ dating of three bulk sediment samples in 210, 510 and $580 \mathrm{~cm}$ depth by the Poznan Radiocarbon Laboratory. Since there is a lack of carbonatic rocks in the lake catchment we exclude an influx of old carbon skewing the ${ }^{14} \mathrm{C} /{ }^{12} \mathrm{C}$ ratio and, thus, the dates were not corrected for a reservoir effect. Calibration of radiocarbon dates was performed using CalPal, a software for calibration and visualization developed and distributed by the Prehistory Institute at University of Cologne (http://www.calpal.de). The calibration curve CalPal2005-SFCP was used. All ages referred to hereafter are calibrated years unless otherwise noted. 

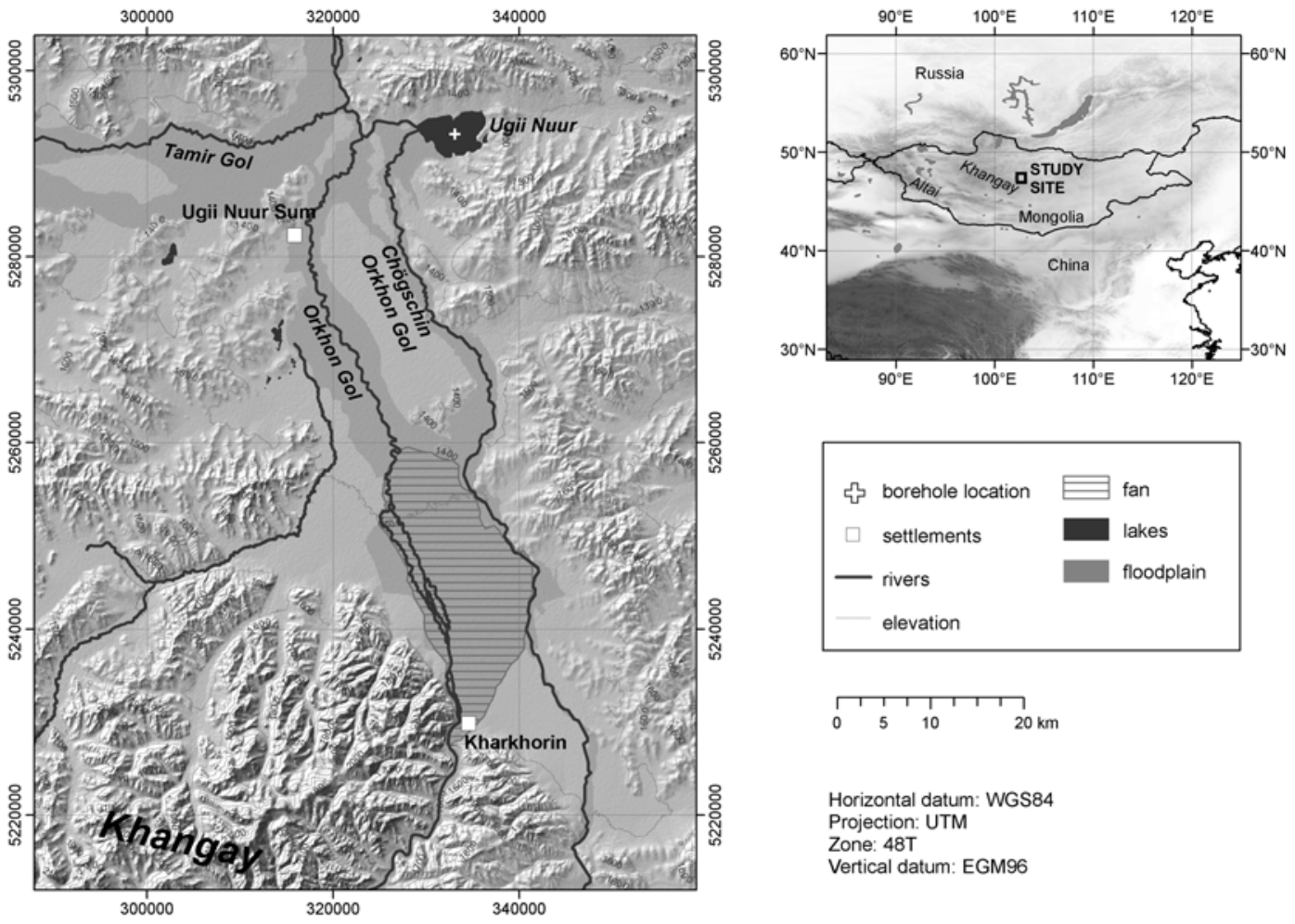

Horizontal datum: WGS84

Projection: UTM

Zone: $48 \mathrm{~T}$

Vertical datum: EGM96

Fig. 1. Map of the Ugii Nuur basin.

\subsection{Statistical analysis}

We applied a principal component analysis (PCA) (Davis, 2002) based on the correlation matrix to reduce the complexity of the elemental composition of the samples. Since compositions only provide information on the relative magnitudes of the components and are subject to a constant sum constraint (CSC), interpretations involving absolute values may be biased (Aitchison, 1999; Aitchison and Egozcue, 2005). Aitchison (1986) presents a solution to the problem of applying multivariate statistics with CSC data by using centered log-ratios, which are linear combinations of the compositional variables. Log-ratios remove the negative bias in the covariance and correlation matrices introduced by the use of CSC data and avoid fallacious interpretations that emerge from raw component analysis (Kucera and Malmgren, 1998). The log-ratio of an observation $i$ of a sample $\mathrm{S}$ is calculated by

$$
y(i)=\ln \left(x(i) / g_{\mathrm{s}}\right),
$$

where $g_{\mathrm{s}}$ is the geometric mean of a sample calculated by

$$
g_{\mathrm{s}}=e^{\left(\ln x_{1}+\ln x_{2}+\ldots+\ln x_{N}\right) / N}
$$

and $N$ is the number of variables constituting the composition in the sample. The presence of zero elements requires a zero-replacement procedure that Aitchison (1986) implements by replacing all zero elements by a value lower than the precision under which the original data were generated (Kucera and Malmgren, 1998).

Prior to log-ratio transformation the unit of all chemical parameters was set to $\mu \mathrm{g} \mathrm{g}^{-1}$. Since our data does not add up to a constant sum (not all elements are determined by the aforementioned analysis techniques), the remaining proportion was included as an additional variable, but was not included in the PCA.

In order to enhance the interpretability of the derived principal components (PCs) as real endmembers they were transformed using Varimax rotation. This orthogonal rotation generates an even distribution of variance on the PCs by maximizing the variance of the factor loadings. Geometrically, the factor loadings are the cosines between the variables and the factors and equal the correlation coefficient. For an interpretation of the factors $50 \%$ declared variance (modulus of factor loading $>0.7$ ) was set as boundary value. The factor scores were estimated using regression in order to gain insight into the chronological behavior of the PCs.

\section{Results}

\subsection{Sediment stratigraphy}

The sediments of the core UGI-4 (Fig. 2) can be distinguished according to three major stratigraphical 


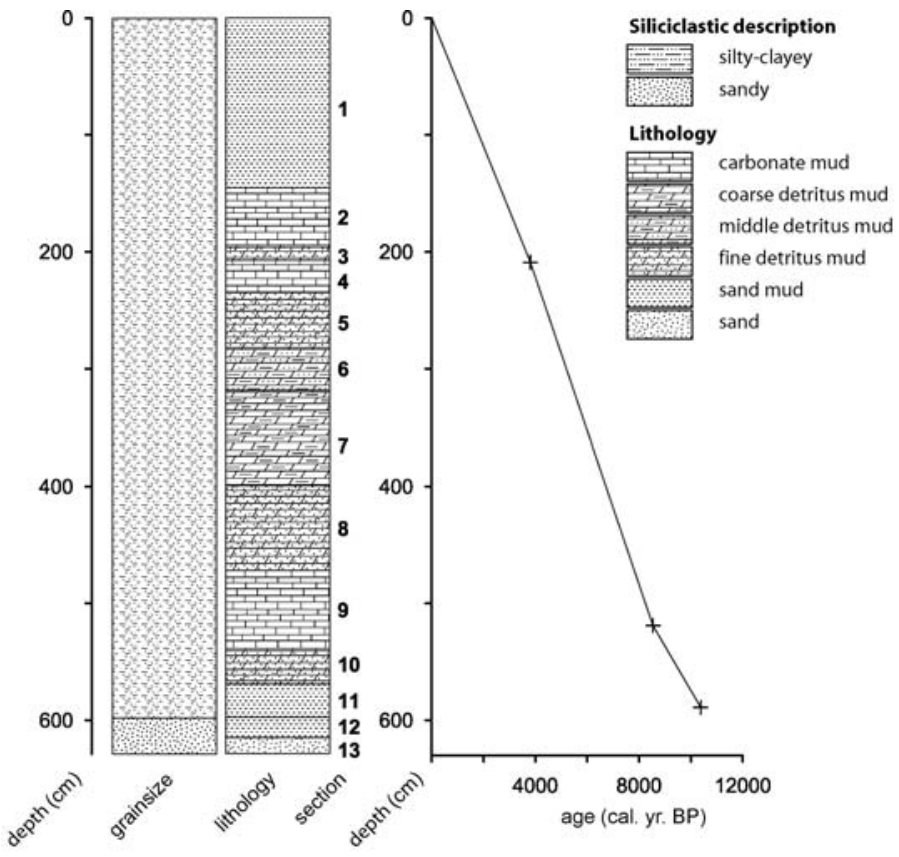

Fig. 2. Lithography and age model of the core Ugi-4.

units characterized by fluvial sands at the bottom (section 12,13 ), clay to silty, organic rich sediments in sections $2-11$ and organic poor loam in the overlying sediments (section $1,<140 \mathrm{~cm}$ ). Sections $2-11$ are mainly determined by alternating carbonate contents locally reaching calcite concentrations up to $30 \%$. A fish scale found in the sediment core in 158-160 cm depth (sediment age of approx. $2800 \mathrm{yr}$ BP corresponding to the age model below) was identified by Joris Peters (LMU Munich) as remnant of a perch (Perca sp.), most likely Perca fluviatilis.

\subsection{Age model}

The AMS ${ }^{14} \mathrm{C}$ dates are $3535 \pm 30$ (Lab. No.: Poz16767), 7770 \pm 50 (Poz-16847) and $9210 \pm 50$ yr BP (Poz-16768), respectively. Calibration of these dates yields $3809 \pm 57,8538 \pm 55$ and $10382 \pm 84$ calibrated (cal.) yr BP. An age model was established by linear interpolation as displayed in Fig. 2. A linear extrapolation at the core end yields a sediment bottom age of $11400 \mathrm{yr}$ BP. Sedimentation rates derived from the linear interpolation range from 0.43 to $0.63 \mathrm{~mm}$ $\mathrm{yr}^{-1}$. Correspondingly, the sampling scheme of $10 \mathrm{~cm}$ intervals sampling rate and $2 \mathrm{~cm}$ resolution is to be equated with a sampling rate of 160-230 years, where each sample integrates over 31-46 years.

\subsection{Element composition}

Element compositions of the sediments are displayed in Fig. 3. Sequences of TIC, Ca, $\mathrm{Mn}$ and $\mathrm{Sr}$ feature various correlative peaks. TIC values range between the detection limit of 0.02 and 3.66 mass- $\%$. Sections of increased TIC concentrations prevail from 530 to $468 \mathrm{~cm}$ and 220 to $158 \mathrm{~cm}$ depth. Further single peaks with amounts up to 2 mass- $\%$ are found in 310, 370, 580 and $590 \mathrm{~cm}$ depth. Except for slightly increased TIC concentrations at the lake bottom, TIC content remains at the detection limit above $150 \mathrm{~cm}$ depth. Fe, $\mathrm{K}, \mathrm{Mg}, \mathrm{Cr}, \mathrm{Cu}$ and Ni show a negative correlation with TIC and TIC-related elements (Fig. 3). Below $600 \mathrm{~cm}$ depth a sharp drop in concentrations coincides with change towards a different depositional environment as indicated by the lithography.

TOC concentrations range between 2 and 8 mass$\%$ above $600 \mathrm{~cm}$ depth. Below $600 \mathrm{~cm}$ the concentrations rapidly decline below the detection limit. Peaks in TIC are partly associated with TOC increases. The TOC graph is characterized by distinct fluctuations throughout the profile. Coherent periods of low TOC values below 3 mass- $\%$ are found from 580 to $538 \mathrm{~cm}$, 470 to $378 \mathrm{~cm}$ and above $150 \mathrm{~cm}$. Some peaks of TOC overlap with increased sulphur concentrations. Here three distinct periods with notably increased S concentrations are observed at 600 to $480 \mathrm{~cm}, 380$ to 310 and 220 to $130 \mathrm{~cm}$ depth. Positive deflexions in TOC concentrations are frequently associated with negative peaks in $\mathrm{K}$ and $\mathrm{Mg}$. $\mathrm{Na}$ and $\mathrm{PO}_{4}$ concentrations are placed together in one group as both feature a trend throughout the profile. $\mathrm{Na}$ has low values of $0.5 \mathrm{mg}$ $\mathrm{g}^{-1}$ at the base of the core and then escalates to 1.5 $\mathrm{mg} \mathrm{g}^{-1}$ at $590 \mathrm{~cm}$ depth. From here a relatively continuous decrease towards $0.5 \mathrm{mg} \mathrm{g}^{-1}$ in the upper part 


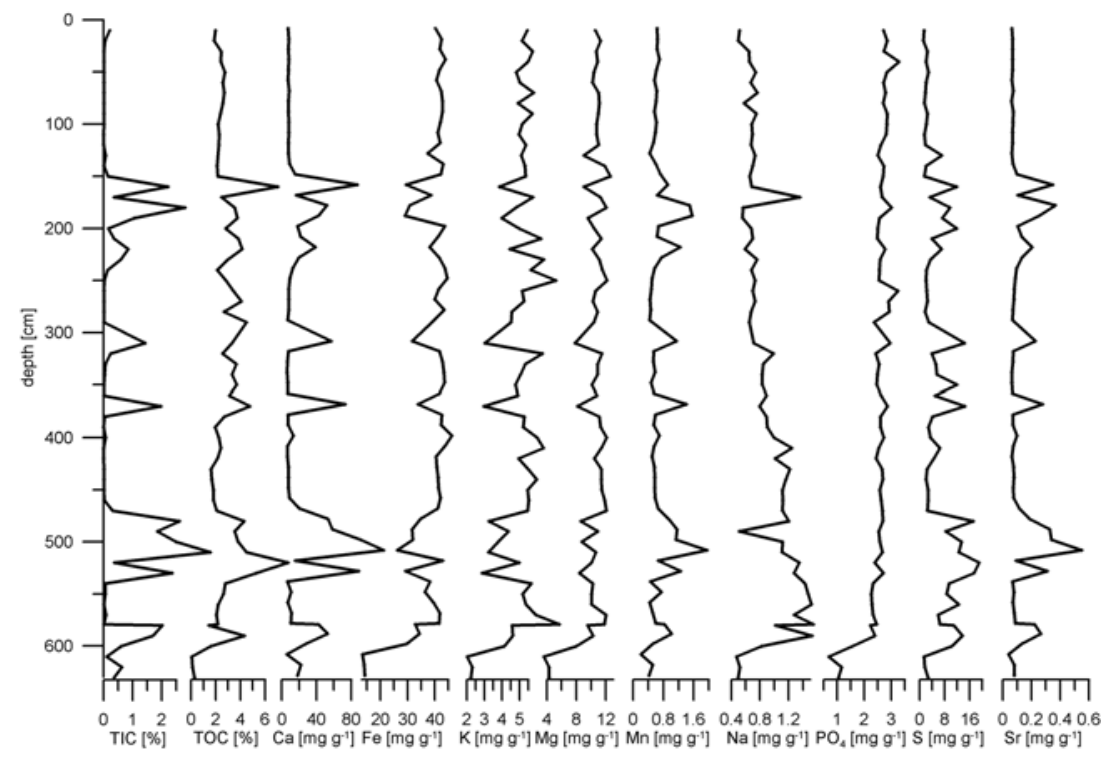

Fig. 3. Element composition of Ugi-4.

Table 1. Eigenvalues and portions of total variable variance contained by the individual principal components before and after Varimax rotation.

\begin{tabular}{|c|c|c|c|c|c|c|}
\hline \multirow[t]{2}{*}{$\mathrm{PC}$} & \multicolumn{3}{|c|}{ Initial eigenvalues } & \multicolumn{3}{|c|}{ Squared loadings after rotation } \\
\hline & Total & $\%$ of variance & Cumulated \% & Total & $\%$ of variance & Cumulated $\%$ \\
\hline 1 & 5.830 & 64.777 & 64.777 & 5.319 & 59.096 & 59.096 \\
\hline 2 & 1.292 & 14.352 & 79.129 & 1.678 & 18.643 & 77.739 \\
\hline 3 & 0.943 & 10.480 & 89.609 & 1.068 & 11.870 & 89.609 \\
\hline 4 & 0.510 & 5.665 & 95.273 & & & \\
\hline 5 & 0.211 & 2.343 & 97.617 & & & \\
\hline 6 & 0.128 & 1.427 & 99.044 & & & \\
\hline 7 & 0.053 & 0.591 & 99.635 & & & \\
\hline 8 & 0.023 & 0.252 & 99.886 & & & \\
\hline 9 & 0.010 & 0.114 & 100.000 & & & \\
\hline
\end{tabular}

of the core is only intermitted by two outliers at 170 and $490 \mathrm{~cm}$ depth. PO also shows low concentrations (approximate $1 \mathrm{mg} \mathrm{g}^{-1}$ ) at the base of the sediment core. Following an erratic increase at $590 \mathrm{~cm}$ depth the curve is characterized by a slightly increasing trend from bottom to top.

\subsection{Principal components}

In order to reduce the complexity of the sediment's chemical character, PCs were extracted from the data described above. As the underlying $30 \mathrm{~cm}$ of the core reflect a fluvial depositional environment, PC analysis was restricted to the core section above $600 \mathrm{~cm}$ depth. The variables included in the PCA are $\mathrm{Ca}, \mathrm{Fe}, \mathrm{K}, \mathrm{Mg}$, $\mathrm{Mn}, \mathrm{S}, \mathrm{Sr}, \mathrm{TIC}$ and TOC. The heavy metals $\mathrm{Cr}, \mathrm{Cu}$, $\mathrm{Ni}$ and $\mathrm{Pb}$ were excluded due to the strong noise associated with their relatively low concentrations close to the detection limit. $\mathrm{Na}$ and $\mathrm{PO}_{4}$ were debared because they have shown to load on a separate factor due to their trend behavior.

Three factors explain $89.6 \%$ of the variance of the variables included in the PCA. After Varimax rotation $59.1 \%$ are attributed to the first, $18.6 \%$ to the second and $11.9 \%$ to the third PC (Table 1 ). The proportions of each variable's variance explained by the extracted PCs (communalities) are listed in Table 2.

The variables are rather distinctly allocated to the PCs. PC1 is associated with TIC, Ca, Fe, K, Mg, S and $\mathrm{Sr}$, whereby $\mathrm{Fe}, \mathrm{K}$ and $\mathrm{Mg}$ are negatively correlated with $\mathrm{PC} 1$. PC2 describes $85 \%$ of the variance of $\mathrm{Mn}$ and a minor part of the variance of $\mathrm{Sr}$ can be attributed to this factor. Strong correlation of PC3 exists solely with TOC.

\subsection{Minerals}

Mineral composition comprises the allogenic and authigenic mineral fraction (Fig. 5). Allogenic minerals constitute the major portion of all samples with 


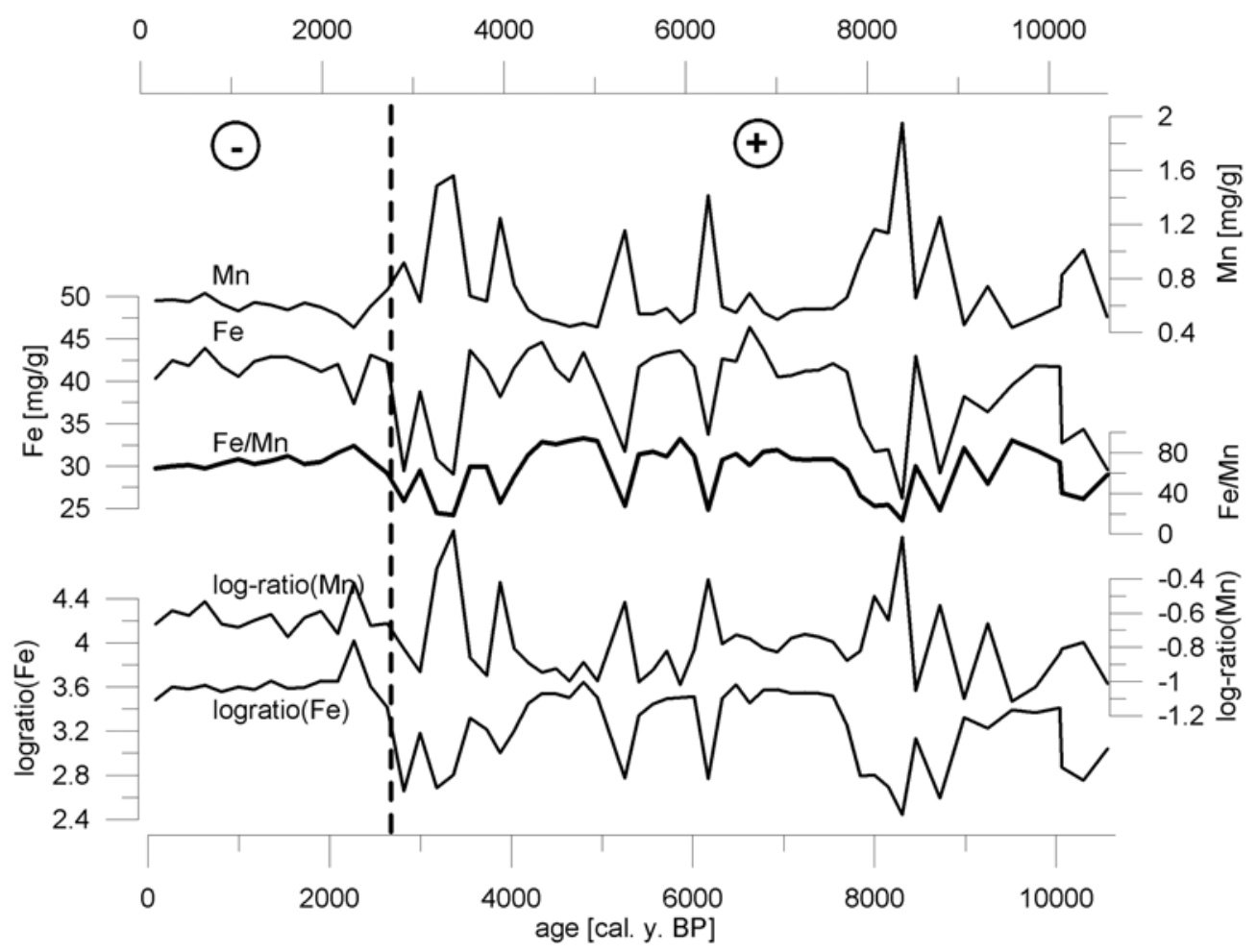

Fig. 4. Compositional and log-ratio transformed Fe, Mn and Fe-Mn ratio. Minus signs signal sections in the core with negative correlation of $\mathrm{Fe}$ and the Fe-Mn ratio, and vice versa.

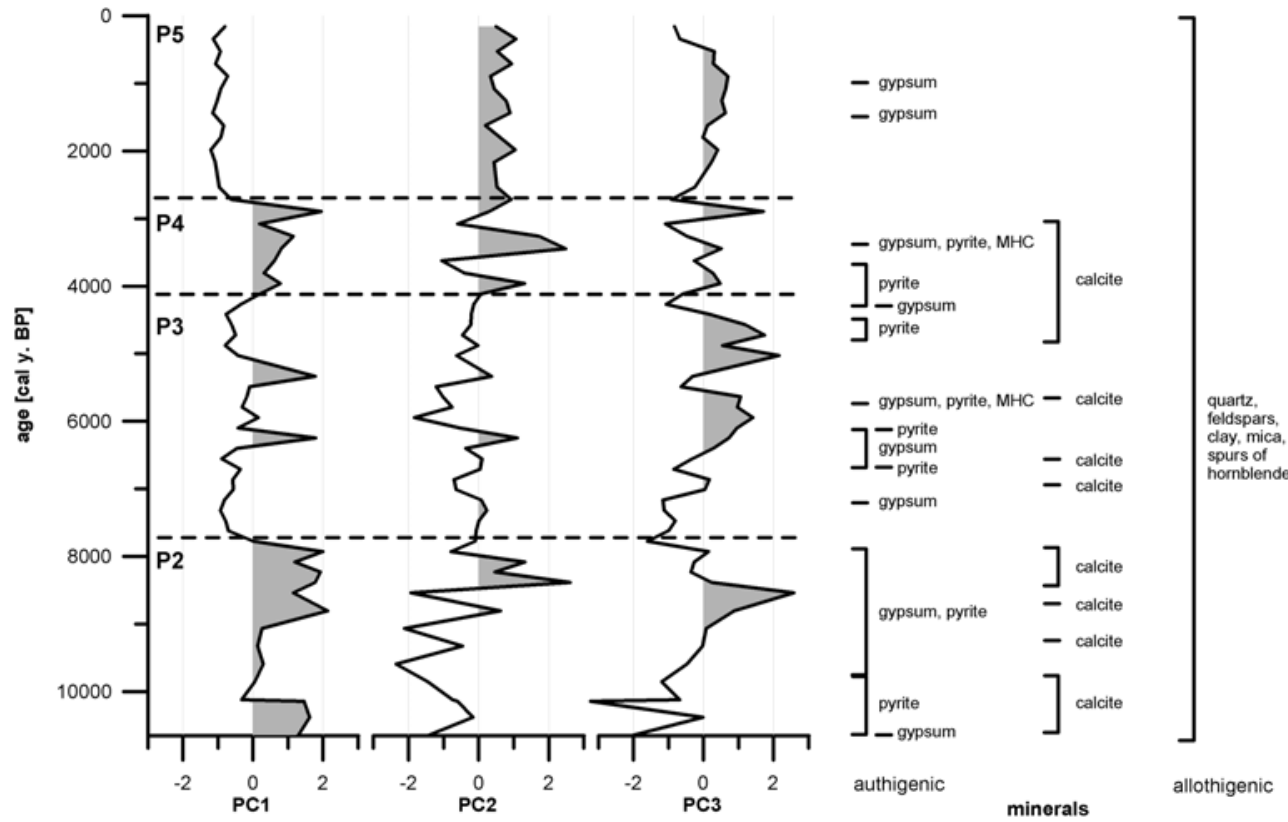

Fig. 5. Chronology of principal components (PC) and occurrences of minerals. 
Table 2. Factor loadings (eigenvectors) and communalities of log-ratio transformed variables after Varimax rotation. Bold numbers indicate factor loading higher $0.7 /$ lower -0.7 .

\begin{tabular}{lrrrr}
\hline Element & \multicolumn{3}{c}{ Factor loading } & Communality \\
\cline { 2 - 4 } & \multicolumn{1}{c}{ PC1 } & \multicolumn{1}{c}{ PC2 } & \multicolumn{1}{c}{ PC3 } & \\
\hline $\mathrm{Mg}$ & $\mathbf{- 0 . 9 7 0}$ & -0.081 & -0.041 & 0.950 \\
$\mathrm{Fe}$ & $\mathbf{- 0 . 9 4 7}$ & -0.214 & 0.054 & 0.946 \\
$\mathrm{~K}$ & $\mathbf{- 0 . 9 2 8}$ & -0.231 & -0.089 & 0.923 \\
$\mathrm{TIC}$ & $\mathbf{0 . 8 8 2}$ & 0.262 & -0.181 & 0.879 \\
$\mathrm{Ca}$ & $\mathbf{0 . 8 5 2}$ & 0.461 & -0.105 & 0.950 \\
$\mathrm{Sr}$ & $\mathbf{0 . 7 5 2}$ & 0.574 & -0.092 & 0.903 \\
$\mathrm{~S}$ & $\mathbf{0 . 7 2 7}$ & -0.332 & 0.145 & 0.660 \\
$\mathrm{Mn}$ & 0.144 & $\mathbf{0 . 9 2 3}$ & -0.012 & 0.872 \\
$\mathrm{TOC}$ & -0.008 & -0.031 & $\mathbf{0 . 9 9 1}$ & 0.983 \\
\hline
\end{tabular}

a dominance of quartz and feldspars. Semiquantitatively determined proportions of quartz and feldspars range between 46 and 94 vol.- $\%$ with a median of 91 vol.- $\%$ for all samples. A differentiation of the feldspar group yields mainly polymorphs of alkali feldspars (orthoclase, sanidine and microcline) and the end-member albite. Further silicates detected as traces are chlorite, hornblende, kaolinite and muscovite.

Calcite is found in 23 samples with concentrations ranging from 1 to 37 vol.-\%. Pyrite and gypsum could be identified in several samples albeit only as traces. Occurrences of pyrite and gypsum are predominantly restricted to the lower and middle part of the profile (Fig. 5) and are mostly associated with calcite. Monohydrocalcite (MHC) is found in two samples in 160 and $310 \mathrm{~cm}$ depth. While in the latter sample, MHC only vestigially occurs, its proportion in the $160 \mathrm{~cm}$ sample is higher than 20 vol.- $\%$.

\section{Discussion}

\section{$5.1 \quad$ Element and mineral composition}

\subsubsection{Interpretation of principal components}

Element and mineral compositions vary in the Ugii Nuur lake sediments. The PCA on the log-ratio transformed element compositions depicts that their variance is basically explained by one factor. Positive loadings on PC1 exist with TIC, $\mathrm{Ca}, \mathrm{Sr}$ and $\mathrm{S}$, elements that mainly reflect the authigenic mineral production in the lake. Positive values of PC1 are consequently interpreted to reflect warm limnic conditions and high biomass production in the lake. This interpretation is based on several aspects. The authigenic production of TIC is subject to various physical lake conditions (temperature, $\mathrm{CO}_{2}$, solute concentration) that are partly linked to biomass production (Håkanson and Jansson, 1983; Dean, 1999; Xiao et al., 2006). Optimal con- ditions for the incorporation of endogenic carbonate minerals in sediments are derived from a combination of these parameters. The water temperature of shallow lakes in summer is generally high and the water body is unstratified due to a lack of sufficient depth to form a hypolimnion in summer, and thus promotes calcite sedimentation. Calcite solubility is further decreased by increasing $\mathrm{pH}$ values during algal blooms (Dean, 1999).

Increased biological activity, however, simultaneously leads to an increase of respiratory $\mathrm{CO}_{2}$ production. This inverse effect on carbonate solubility is presumably buffered by allogenic contribution of calcite to the lake (Håkanson and Jansson, 1983). Due to an absence of carbonate rocks in the Ugii Nuur catchment, the input of calcite derived from bedrock solution can be excluded. Yet, it was shown by Lehmkuhl and Lang (2001) and Grunert and Lehmkuhl (2004) that carbonatic loess-like deposition plays an important role in the sediment budget of the Mongolian steppe regions. Direct aeolian deposition in the lake and input of calcium carbonate or its solutes by removal of aeolian deposits by water erosion may be an important carbonate source for lacustrine carbonate precipitation. Moreover, the proportion of allogenic calcite in the lake is linked to the lake volume. The assumption of a decreased lake volume during high values of PC1 is further consolidated by a preponderant cooccurrence of authigenic minerals like pyrite and gypsum (Fig. 5). While sulfides are formed under highly reduced conditions and thus indicate productive lakes (Håkanson and Jansson, 1983), sulfates are primarily precipitated from solutions with densities higher than $1.115 \mathrm{~g} \mathrm{~cm}^{-1}$ and thus indicate increased salinity driven by evaporation (Langbein, 1961; Sonnenfeld, 1984; Schütt, 2004b).

The elements $\mathrm{K}, \mathrm{Mg}$ and $\mathrm{Fe}$ negatively relate to PC1 and are interpreted as lithogenous or allogenic sediment fraction. Despite the removal of possible dilution effects on the data by log-ratio transformation, the diametrical behavior between authigenic and allogenic sediments remains. Thus, negative values of PC1 are related to high lake levels and increased detrital input. The results from the upper part of the sediment core reflect this situation and are confirmed by the current state of the water body that is characterized as oligo- to mesotrophic and thermally stratified (Völker, 2005). Higher lake levels than present are expected to exceed the present state by a maximum of only two meters due to a lack of damming to the west of the basin and a consequent overflow to the Orkhon River (Fig. 1).

Mn variability is assigned to an independent mechanism described by $\mathrm{PC} 2$. Mn, in lacustrine sediments, 
is sensitive to lake and catchment conditions and is often compared to Fe by means of the Fe-Mn ratio (Mackereth, 1966; Boyle, 2001; Schütt, 2004b). A comparison of $\mathrm{Fe}$ and the Fe-Mn ratio (Fig. 4) reveals that the relation between both elements varies along the core. While in the upper part Fe and the Fe-Mn ratio graphs exhibit an opposing course, parallel behavior prevails in the lower part of the core. As aforementioned, $\mathrm{Fe}$ is related to the lithogenous sediment fraction, which indicates a strong erosional mode of transport of this element (Hartmann and Wünnemann, 2008). The parallel course of Fe and Mn in the upper part of the core is characterized by high $\mathrm{Fe}$ and low Mn concentrations in comparison to the concentration range of both. Mn concentrations during this phase presumably equal those of the lithospheric background (Mackereth, 1966). The underlying part of the core $(>160 \mathrm{~cm}$ depth, $>2.8 \mathrm{kyr} \mathrm{BP})$ is characterized by much stronger fluctuations of both elements. Sharp increases in Mn contents are always accompanied by negative Fe-concentrations. As low contents of Fe indicate an attenuation of the lithogenic sediment fraction, the correlating high contents of Mn point towards a different source of Mn. We suggest that these phases are marked by low allothigenic input by surface runoff and that the lake is predominantly fed by groundwater. Since Mn in soils is more easily mobilized than iron under reducing conditions (Schlichting and Schweikle, 1980), groundwater is enriched in dissolved Mn, which is subsequently incorporated in the lake sediments. This assumption is consolidated by the medium PC2 loadings of $\mathrm{Ca}$ and $\mathrm{Sr}$ (Table 2), that are highly mobile in soils, too (Scheffer, 2002). As a consequence we interpret $\mathrm{PC} 2$ to reflect solute transport from the catchment via groundwater into the lake. A positive trend of $\mathrm{PC} 2$ thus indicates aquifer filling and soil formation during the Holocene.

PC3 reflects the mechanism behind TOC accumulation in the lake sediments. TOC enrichment can be attributed to increased autochthonous bioproduction, dedrital input from the catchment (Dunne et al., 1991; Boyle, 2001; Xiao et al., 2006) and preservation, when covering rates exceed diagenetic decomposition rates (Lerman, 1979; Schütt, 2004a). These diverse mechanisms impede paleoclimatological interpretations inferred from TOC concentrations without additional source signals (e.g., N, $\delta^{13} \mathrm{C}$ ) (Meyers, 1994; Xiao et al., 2006; Hartmann and Wünnemann, 2008). Still, various correlative peaks of TIC and TOC suggest a synsedimentary mechanism during some periods. Since TIC is interpreted to negatively correspond with waterdepth, TOC concentrations during low lake levels may largely reflect increased biological productivity (Scheffer, 2004). Yet, relatively high TOC con- centrations $(\sim 2 \%)$ prevalent during high lake levels and suggest the additional influence of terrestrial organic matter (plant detritals, humins) transported to lake via groundwater or overland flow (Xiao et al., 2006).

\subsubsection{Monohydrocalcite}

A rather rare mineral found in 160 and $310 \mathrm{~cm}$ depth is $\mathrm{MHC}\left(\mathrm{CaCO}_{3} \cdot \mathrm{H}_{2} \mathrm{O}\right)$. The natural occurrence of this hydrated calcium carbonate was first reported by Sapozhnikov and Tsvetkov (1959) in the form of calcareous incrustations on the bottom near the shore of Lake Issyk-Kul, Kirgistan. It has been found by Marschner (1969) at the mouths of cold water pipes, by Taylor (1975) as a main constituent in beach rocks in southern Australia and by Fischbeck and Müller (1971) and Harmon (1983) in speleothems. A marine occurrence of MHC has been first reported by Dahl and Buchardt (2006) for south-west Greenland.

MHC formation is attributed to several mechanisms. Laboratory experiments suggest a preferable MHC genesis at water temperatures near the freezing point (Lippmann, 1973) and natural occurrences have often been associated with cold water (Marschner, 1969; Fischbeck and Müller, 1971; Harmon, 1983). Yet, biological activity is also regarded as an important mechanism behind MHC formation (Broughton, 1972; Taylor, 1975; Skinner et al., 1977). Since it was shown that MHC tends to convert to anhydrous carbonates even at low temperatures (several authors in Lippmann, 1973), a stable basis for the interpretation of $\mathrm{MHC}$ as proxy for lake temperatures is lacking.

\subsubsection{Paleoenvironmental implications}

Datings point to an onset of lacustrine sedimentation in the Ugii Nuur lake at $10.6 \mathrm{kyr}$ BP after a period of fluvial deposition most likely by the Orkhon or Old Orkhon River [Phase 1 (P1)] (Walther and Gegeensuvd, 2005). The temporal placement is in good agreement with other lakes in NW China and Mongolia that predominantly featured a negative water balance or were dried out during the Last Glacial Maximum (LGM) and the beginning of the Holocene (Grunert and Dasch, 2004; Hartmann and Wünnemann, 2008; Karabanov et al., 2004; Tarasov et al., 1999; Walther, 1999; Walther et al., 2003; Wünnemann et al., 1998; Wünnemann and Hartmann, 2002; Yang et al., 2004). Rapid increases in lake levels may be attributed to meltwater generated by the glacier retreat after the LGM (Walther, 1999). Yet, the occurrence of glaciers in the Ugii Nuur basin was limited to the higher regions of the Khangay Mountains (Lehmkuhl et al., 2004). Lake level rise may also be linked to the abrupt monsoon intensification at $\sim 11.5 \mathrm{kyr}$ BP (Sirocko et 
al., 1993; Wang et al., 1999; Herzschuh, 2006).

PC1 scores indicate a generally lower lake level than today with high biological productivity during the early phase of lake evolution from 10.6 to $7.9 \mathrm{kyr}$ $\mathrm{BP}$ (P2, Fig. 5). Low values of PC3 point to efficient decomposition during the underlying half of this section but might also indicate a poor availability of organic matter from the catchment. The findings of gypsum, pyrite and generally low but partly moderate concentrations of calcite in this section support the notion of the high lake internal productivity and a lack of outflow and evaporation driven water balance during this time. From 10.1 to 9.1 kyr BP PC1 values around zero point at a well-balanced ratio between deposition of authigenic and allogenic material during moderate lake levels. Lake desiccation from 9.1 to $7.9 \mathrm{kyr} \mathrm{BP}$ is in good agreement with a marked dry phase observed in NW China and the Tibetan Plateau (Herzschuh, 2006; Wünnemann et al., 2003; Xiao et al., 2004; Hartmann and Wünnemann, 2008) and might be attributed to the $8.2 \mathrm{kyr} \mathrm{BP}$ event (Alley and Agustsdottir, 2005). These results, however, disagree with evidences of wetter conditions in $\mathrm{NW}$ Mongolia inferred from the rise of boreal evergreen and conifer pollen since 9 kyr BP (Tarasov et al., 2000).

A subsequent phase of high lake levels interrupted by a period with pronounced fluctuations occurred from 7.9 to $4.2 \mathrm{kyr} \mathrm{BP}$ (P3, Fig. 5). During this time allogenic material is dominantly supplied to the lake bottom indicating increased runoff. Vegetation during this time was characterized by an increase in woodland (Rösch et al., 2005). A marked increase in PC3 suggests the importance of detrital organic input and its poor decomposition during this period. In arid and semi-arid China most sites archive a relatively wet climate during the Mid Holocene (7-5 kyr BP) (e.g., Xiao et al., 2004, 2006) but spatial patterns among different lakes are inconsistent (An et al., 2006; Hartmann and Wünnemann, 2008). High water levels are reported for most Mongolian lakes during the Mid-Holocene (Dorofeyuk and Tarasov, 1998; Grunert et al., 2000; Tarasov et al., 2000). Yet, Peck et al. (2002) and Fowell et al. (2003) indicate a Mid Holocene dry climate for Lake Telmen. Corresponding to the irregular spatial pattern of moisture availability, the temporal lake level pattern as observed in P3 and the sporadic occurrences of pyrite and gypsum during this period reflect a rather unstable development of the lake during the Mid Holocene and a higher sampling rate is required to reliably resolve these fluctuations.

From 4.2 to 2.8 kyr BP (P4, Fig. 5) a phase of reduced lake levels is indicated by $\mathrm{PC} 1$. Constant calcite precipitation and occurrences of pyrite and gypsum suggest high biological activity and salinity of the lake water during this time. This period agrees fairly well with the temporal placement of a dry phase from 5.4 to 2.9 kyr BP observed in Mongolia (Walther et al., 2003) and northwest China (Xiao et al., 2004) and correlates with a rapid decline of forest vegetation and a re-establishment of steppe as the dominant vegetation type in the Hoton-Nuur area at 4 kyr BP (Tarasov et al., 2000). Still, evidence for a more humid phase in Central Mongolia during this period is provided by Peck et al. (2002).

The Ugii Nuur record indicates stable high lake levels from $2.8 \mathrm{kyr} \mathrm{BP}$ to present (P5, Fig. 5), thus suggesting enhanced moisture supply during the Late Holocene. Although an onset of more humid conditions is reported during the beginning of the Late Holocene for areas in NW China and Mongolia (Hartmann and Wünnemann, 2008; Peck et al., 2002; Walther et al., 2003), evidence for a trend towards dryer conditions during the last three millennia is found in many parts of Central Asia except for those influenced by the westerlies (Herzschuh, 2006).

The chronology of the factor scores and their palaeoenvironmental interpretation partly agrees with previous findings from Central and East Asia. Nevertheless, they partly disagree with findings from other sites located relatively close to the Ugii Nuur basin [e.g., Lake Telmen (Peck et al., 2002; Fowell et al., 2003)]. This highlights the problems associated with the ability to transfer the findings to a larger area and, thus, points to the difficulties that arise from the deduction of information on the general paleoenvironmental conditions. Spatially variable palaeoenvironmental conditions in NW China are mainly associated with the southward retreat of the South-East Asian Monsoon since 9 kyr BP (An et al., 2000) and the response of the Indian Monsoon and the westerlies (Herzschuh, 2006). Still, extreme differences exist among sites located close to each other (Herzschuh, 2006). Partly, the alternating timings of dry and wet intervals may be explained by site-specific sensitivities to moisture supply (An et al., 2006). These sitespecific sensitivities may be derived from the present aridity of a location (An et al., 2006), but processes like aquifer response to moisture supply should also be taken into account (Hartmann and Wünnemann, 2008). Hence, in order to reduce the uncertainties associated with the interpretation of lake sediments, not only a larger quantity of lake proxies should be considered. Moreover, spatially distinct terrestrial archives should be investigated to understand catchment response to climate variability.

\section{Conclusions and outlook}

Lacustrine deposits of Lake Ugii Nuur provide valu- 
able insights into the palaeoenvironmental evolution of the Ugii Nuur basin and the adjacent Orkhon Valley. During the Holocene the lake environment altered between open and closed lake conditions. Lacustrine deposition started at 10.6 kyr BP. Low lake level conditions were identified during the Early Holocene (10.6$7.9 \mathrm{kyr} \mathrm{BP})$. It is proposed that lakes in this area benefitted from increased discharge induced by glacier melting in the Khangay Mountains during a warm but relatively arid period. The Mid Holocene (7.9-4.2 kyr BP) was characterized by generally higher lake levels and thus increased moisture supply. Yet, this period was prone to strong climatic fluctuations. More arid conditions prevailed from 4.2-2.8 kyr BP and were followed by a stable, more humid phase until today.

Archaeological findings provide evidences for the earliest human settlements in the Orkhon Valley more than two thousand years $(\sim 250$ yr BP $)$ ago. Since then, the Orkhon Valley was a preferred settlement location of various cultures (Weiers, 2005). Remnants of walls, necropoles and memorials found all over the area testify this long history of human interference with the environment in this region (Bemmann et al., 2008). A climax phase of human activities in this area represents the late Medieval, when Dschingis Khan chose the fan deposits of the Upper Orkhon Valley as locality for the Mongolian capital Karakorum (Qara Qorum). A question always was: Why was this area chosen again and again? We conclude, that, among many reasons, the three millennia lasting, favorable and stable environmental conditions in this area were at least an important factor.

Acknowledgements. We would like to thank Mrs. E. Krings and Dr. H.-P. Röper for assistance in X-ray diffractometry and Prof. Dr. Joris Peters from LMU Munich for the identification of the fishscale.

\section{REFERENCES}

Aitchison, J., 1986: The Statistical Analysis of Compositional Data. Monographs on Statistics and Applied Probability, Chapman \& Hall, Ltd., London, 416pp.

Aitchison, J., 1999: Logratios and natural laws in compositional data analysis. Mathematical Geology, 31, $563-580$.

Aitchison, J., and J. J. Egozcue, 2005: Compositional data analysis: Where are we and where should we be heading. Mathematical Geology, 37, 829-850.

Alley, R. B., and A. M. Agustsdottir, 2005: The 8k event: Cause and consequences of a major Holocene abrupt climate change. Quaternary Science Reviews, 24, 1123-1149.

An, C.-B., L. Tang, L. Barton, and F.-H. Chen, 2005: Climate change and cultural response around $4000 \mathrm{cal}$ yr B.P. in the western part of Chinese Loess Plateau.
Quaternary Research, 63, 347-352.

An, C.-B., Z.-D. Feng, and L. Barton, 2006: Dry or humid? Mid-Holocene humidity changes in arid and semi-arid China. Quaternary Science Reviews, 25, $351-361$.

An, Z., 2000: The history and variability of the East Asian paleomonsoon climate. Quaternary Science Reviews, 19, 171-187.

An, Z., S. P. Porter, J. E. Kutzbach, X. Wu, S. Wang, X. Liu, X. Li, and W. Zhou, 2000: Asynchronous Holocene optimum of the East Asian monsoon. Quaternary Science Reviews, 19, 743-762.

Bemmann, J., E. Pohl, B. Schütt, and W. Schwanghart, 2008: Archeological findings in the Upper and Middle Orchon Valley and their geographical setup. Mongolian-German Qara Qorum-Expedition, Bemmann et al., Eds., FAAK (Forschungen zur Archäologie Auäereuropäischer Kulturen), in press.

Boyle, J. F., 2001: Inorganic geochemical methods in paleolimnology. Tracking Environmental Change Using Lake Sediments. Physical and Geochemical Methods. Vol. 2, Developments in Paleoenvironmental Research, W. M. Last and J. P. Smol, Kluwer, Eds., Dordrecht, Boston, London, 83-142.

Broughton, P. L., 1972: Monohydrocalcite in speleothems: An alternative interpretation. Contributions to Mineralogy and Petrology, 36, 171-174.

Dahl, K., and B. Buchardt, 2006: Monohydrocalcite in the Arctic Ikka Fjord, SW Greenland: First Reported Marine Occurrence. Journal of Sedimentary Research, 76, 460-471.

Davis, J. C., 2002: Statistics and Data Analysis in Geology. John Wiley \& Sons, New York, Chichester, Brisbane, 3 Ed., 638pp.

Dean, W. E., 1999: The carbon cycle and biogeochemical dynamics in lake sediments. Journal of Paleolimnology, 21, 375-393.

Dorofeyuk, N. I., and P. E. Tarasov, 1998: Vegetation and lake levels in Northern Mongolia in the last 12,500 years as indicated by data of pollen and diatom analyses. Stratigraphy and Geological Correlation, 6, 7083.

Dulamsuren, C., M. Hauck, and M. Mühlenberg, 2005: Ground vegetation in the Mongolian taiga foreststeppe ecotone does not offer evidence for the human origin of grasslands. Applied Vegetation Science, 8, $149-154$.

Dunne, T., W. Zhang, and B. Aubry, 1991: Effects of rainfall, vegetation and microtopography on infiltration and runoff. Water Resour. Res., 27, 2271-2285.

Fang, X. M., and Coauthors, 1999: Asian summer monsoon instability during the past 60,000 years: magnetic susceptibility and pedogenic evidence from the western Chinese Loess Plateau. Earth and Planetary Science Letters, 168, 219-232.

Fischbeck, R., and G. Müller, 1971: Monohydrocalcite, hydromagnesite, nesquehonite, dolomite, aragonite and calcite in speleothems of the Fränkische Schweiz, Western Germany. Contributions to Mineralogy and 
Petrology, 33, 87-92.

Fowell, S. J., B. C. Hansen, J. A. Peck, P. Khosbayar, and E. Ganbold, 2003: Mid to late Holocene climate evolution of the Lake Telmen basin, north central Mongolia, based on palynological data. Quaternary Research, 59, 353-363.

Fu, C., and F. P. de Vries, 2006: Initial science plan of the Monsoon Asia Integrated Study, MAIRS working paper series, Vol. 1, International Program Office, MAIRS, 86pp.

Grunert, J., and D. Dasch, 2004: Dynamics and evolution of dune fields on the northern rim of the Gobi Desert (Mongolia). Zeitschrift Für Geomorphologie Suppl., 133, 81-106.

Grunert, J., and F. Lehmkuhl, 2004: Aeolian sedimentation in arid and semi-arid environments of Western Mongolia. Paleoecology of Quaternary Drylands, W. Smykatz-Kloss and P. Felix-Henningsen, Eds., Vol. 102, Lecture Notes in Earth Sciences, Springer, Berlin, New York, Toronto, 195-218.

Grunert, J., F. Lehmkuhl, and M. Walther, 2000: Paleoclimatic evolution of the Uvs Nuur basin and adjacent areas (Western Mongolia). Quaternary International, 65-66, 171-192.

Gunin, P. D., E. A. Vostokova, N. I. Dorofeyuk, P. E. Tarasov, and C. C. Black, 1999: Vegetation Dynamics of Mongolia, Geobotany. Vol. 26, Kluwer, Dordrecht, Boston, London, 233pp.

Haase, G., 1983: Beiträge zur Bodengeographie der Mongolischen Volksrepublik. Physisch-Geographische Studien in Asien, Barthel et al., Eds., 34, 231-367. (in German)

Håkanson, L., and M. Jansson, 1983: Principles of Lake Sedimentology. Springer, Berlin, Heidelberg, New York, 316pp.

Hartmann, K., and B. Wünnemann, 2008: Hydrological changes and Holocene climate variations in NW China, inferred from lake sediments of Juyanze palaeolake by factor analyses. Quaternary International, doi: 10.1016/j.quaint.2007.06.037.

Harmon, R. S., 1983: The mineralogy of Castleguard Cave, Columbia Icefields, Alberta, Canada. Arctic and Alpine Research, 15, 503-516.

Herzschuh, U., 2006: Palaeo-moisture evolution in monsoonal Central Asia during the last 50,000 years. Quaternary Science Reviews, 25, 163-178.

Hilbig, W., 1995: The Vegetation of Mongolia. SPB Academic Publishing, 260pp.

Karabanov, E. B., and Coauthors, 2004: Ecological collapse of Lake Baikal and Lake Hovsgol ecosystems during the Last Glacial and consequences for aquatic species diversity. Palaeogeography, Palaeoclimatology, Palaeoecology, 209, 227-243.

Kucera, M., and B. A. Malmgren, 1998: Logratio transformation of compositional data-A resolution of the constant sum constraint. Marine Micropaleontology, 34, 117-120.

Langbein, W. B., 1961: Salinity and hydrology of closed lakes. U. S. Geology Survey Professional Paper, 421,
$1-20$.

Lehmkuhl, F., and A. Lang, 2001: Geomorphological investigations and luminescence dating in the southern part of the Khangay and the Valley of the Gobi Lakes (Central Mongolia). Journal of Quaternary Science, 16, 69-87.

Lehmkuhl, F., M. Klinge, and G. Stauch, 2004: The extent of Late Pleistocene glaciations in the Altai and Khangai Mountains. Quaternary Glaciations Extent and Chronology. Part III: South America, Asia, Africa, Australasia, Antarctica, J. Ehlers and P. L. Gibbard, Eds., Elsevier, Amsterdam, Boston, Heidelberg, Vol. 2, Developments in Quaternary Science, 243-254.

Lerman, A., 1979: Geochemical Processes, Water and Sediment Environment. John Wiley and Sons, New York, 480pp.

Lippmann, F., 1973: Sedimentary Caronate Minerals, Minerals, Rocks and Inorganic Materials. Monograph Series of Theoretical and Experimental Studies, Vol. 6, Springer, Berlin, Heidelberg, New York, 228pp.

Liu, J., and J. Diamond, 2005: China's environment in a globalizing world. Nature, 453, 1179-1186.

Liu, Q., S. K. Banerjee, M. J. Jackson, C. Deng, Y. Pan, and R. Zhu, 2005: Inter-profile correlation of the Chinese loess/paleosol sequences during Marine Oxygen Isotope Stage 5 and indications of pedogenesis. Quaternary Science Reviews, 24, 195-210.

Mackereth, F. J. H., 1966: Some chemical observations on post-glacial lake sediments. Philosophical Transactions of the Royal Society B, 250, 165-213.

Madsen, D. B., L. Jingzen, R. G. Elston, X. Cheng, R. L. Bettinger, G. Kan, P. J. Brantingham, and Z. Kan, 1998: The loess/paleosol record and the nature of the younger dryas climate in Central China. Geoarchaeology: An International Journal, 13, 847-869.

Maher, B. A., and R. Thomson, 1991: Mineral magnetic record of the Chinese loess and paleosols. Geology, 19, 3-6.

Marschner, H., 1969: Hydrocalcite $\left(\mathrm{CaCO}_{3} \cdot \mathrm{H}_{2} \mathrm{O}\right)$ and nesquehonite $\left(\mathrm{MgCO}_{3} \cdot 3 \mathrm{H}_{3} \mathrm{O}\right)$ in carbonate scales. Science, 165, 1119-1121.

Meyers, P. A., 1994: Preservation of elemental and isotopic source identification of sedimentary organic matter. Chemical Geology, 114, 289-302.

Opp, C., and W. Hilbig, 2003: Verbreitungsregeln von Böden und Pflanzengesellschaften im nördlichen Zentralasien unter besonderer Berücksichtigung des UvsNuur-Beckens. Petermanns Geographische Mitteilungen, 147, 16-23. (in German)

Peck, J. A., P. Khosbayar, S. J. Fowell, R. B. Pearce, S. Ariunbileg, B. C. Hansen, and N. Soninkhishig, 2002: Mid to Late Holocene climate change in north central Mongolia as recorded in the sediments of Lake Telmen. Palaeogeography, Palaeoclimatology, Palaeoecology, 183, 135-153.

Prokopenko, A. A., G. K. Khursevich, E. V. Bezrukova, M. I. Kuzmin, X. Boes, D. F. Williams, S. A. Fedenya, N. V. Kulagina, P. P. Letunova, and A. A. 
Abzaeva, 2007: Paleoenvironmental proxy records from Lake Hovsgol, Mongolia, and a synthesis of Holocene climate change in the Lake Baikal watershed. Quaternary Research, 68, 2-17.

Rösch, M., E. Fischer, and T. Märkle, 2005: Human diet and land use in the time of the KhansArchaeobotanical research in the capital of the Mongolian Empire, Qara Qorum, Mongolia. Vegetation History and Archaeobotany, 14, 485-492.

Rost, K. T., J. Böhner, and K.-H. Pörtge, 2003: Landscape degradation and desertification in the $\mathrm{Mu}$ Us Shamo, Inner Mongolia-an ecological and climatic problem since historical times? Erdkunde, 57, 110125.

Sapozhnikov, D. G., and A. I. Tsvetkov, 1959: Precipitation of hydrous calcium carbonate on the bottom of Lake Issyk-Kul. Dokl. Akad. Nauk SSSR, 124, 402405.

Scheffer, F., 2002: Lehrbuch der Bodenkunde/Scheffer/ Schachtschabel. Spektrum, Heidelberg, Berlin, 15 Ed., 593pp. (in German)

Scheffer, M., 2004: Ecology of Shallow Lakes, Population and Community Biology Series, Vol. 22, Kluwer Academic Publishers, Dordrecht, Boston, London, 394pp.

Schlichting, E., and V. Schweikle, 1980: Interpedon translocations and soil classification. Soil Science, 130, 200-204.

Schütt, B., 2004a: The chemistry of playa-lake-sediments as a tool for the reconstruction of Holocene environmental conditions-A case study from the central Ebro basin. Paleoecology of Quaternary Drylands, W. Smykatz-Kloss and P. Felix-Henningsen, Eds.. Vol. 102, Lecture Notes in Earth Sciences, Springer, Berlin, New York, Toronto, 5-30.

Schütt, B., 2004b: Zum holozänen Klimawandel der zentralen Iberischen Halbinsel, Relief Boden Paläoklima. Vol. 2, Bornträger, Berlin, Stuttgart, 347pp. (in German)

Schwanghart, W., and B. Schütt, 2008: Holocene morphodynamics in the Ugii Nuur basin, Mongoliainsights from a sediment profile and 1D electrical resistivity tomography. Zeitschrift für Geomorphologie, in press.

Sirocko, F., M. Sarntheim, H. Erlenkeuser, H. Lange, M. Arnold, and J. C. Duplessy, 1993: Century-scale events in monsoonal climate over the past 24,000 years. Nature, 364, 322-324.

Skinner, H. C. W., G. W. Osbaldiston, and A. N. Wilner, 1977: Monohydrocalcite in a guinea pig bladder stone, a novel occurrence. American Mineralogist, 62, 273-277.

Sladen, C., and J. J. Traynor, 2000: Lakes during the evolution of Mongolia. Lake Basins Through Space and Time, E. H. Gierlowski-Kordesch and K. R. Kelts, Eds., Vol. 46, American Association of Petroleum Geologists Studies in Geology, 35-57.

Sonnenfeld, P., 1984: Brines and Evaporites. Academic Press, Orlando, 613pp.
Tarasov, P., N. Dorofeyuk, and E. Metel'Tseva, 2000: Holocene vegetation and climate changes in HotonNur basin, northwest Mongolia. Boreas, 29, 117-126.

Tarasov, P. E., and Coauthors, 1999: Last Glacial Maximum climate of the former Soviet Union and Mongolia reconstructed from pollen and plant macrofossil data. Climate Dyn., 15, 227-240.

Taylor, G. F., 1975: The occurrence of monohydrocalcite in two small lakes in the south-east of South Australia. American Mineralogist, 60, 690-697.

Thompson, L. G., and Coauthors, 1997: Tropical climate instability: The last glacial cycle from a QuighaiTibetan ice core. Science, 276, 1821-1825.

Traynor, J. J., and C. Sladen, 1995: Tectonic and stratigraphic evolution of the Mongolian People's Republic and its influence on hydrocarbon geology and potential. Marine and Petroleum Geology, 12, 35-52.

Völker, J., 2005: Hydrographie und aktueller Gewässerzustand. Ugii Nuur (Central Mongolia) Paleoenvironmental Studies of Lake Level Fluctuations and Holocene Climate Change, M. Walther and T. Gegeensuvd, Eds., Vol. 2, Geographica-Oekologica, MOLARE Research Centre, Ulaanbaatar, 2-6. (in German)

Walther, M., 1999: Befunde zur jungquartären Klimaentwicklung rekonstruiert am Beispiel der Seespiegelstände des Uvs Nuur-Beckens (NWMongolei). Die Erde, 130, 131-150. (in German)

Walther, M., and T. Gegeensuvd, 2005: Ugii Nuur (Central Mongolia) Paleo Environmental Studies of Lake Level Fluctuations and Holocene Climate Change, Geographica-Oekologica, Vol. 2, MOLARE Research Centre, Ulaanbaatar, 36pp.

Walther, M., B. Wünnemann, and A. Tschimeksaichan, 2003: Seen und Paläoseen in der Mongolei und Nordwestchina. Petermanns Geographische Mitteilungen, 147, 40-47. (in German)

Wang, L., and Coauthors, 1999: East Asian monsoon climate during the Late Pleistocene: High-resolution sediment records from the South China Sea. Marine Geology, 156, 245-284.

Wang, Y. J., H. Cheng, R. L. Edwards, Z. S. An, Y. Wu, J, C.-C. Shen, and J. A. Dorale, 2001: A highresolution absolute-dated Late Pleistocene monsoon record from Hulu Cave, China. Science, 294, 23452348.

Weiers, M., 2005: Steppe und Steppenreiche bis Cinggis Khan. Dschingis Khan und seine Erben, Hirmer, 36-38. (in German)

Wünnemann, B., and K. Hartmann, 2002: Morphodynamics and Paleohydrography of the Gaxun Nur Basin, Inner Mongolia, China. Zeitschrift für Geomorphologie Suppl., 126, 147-168.

Wünnemann, B., H. Pachur, and J. Li, 1998: Chronologie der pleistozänen und holozänen Seespiegelschwankungen des Gaxun Nur / Sogo Nur und Baijian $\mathrm{Hu}$, Innere Mongolei, Nordwestchina. Petermanns Geographische Mitteilungen, 142, 191-206. (in German) 
Wünnemann, B., F. Chen, F. Riedel, C. Zhang, S. Mischke, G. Chen, D. Demske, and J. Ming, 2003: Holocene lake deposits of Bosten Lake, southern Xinjiang, China. Chinese Science Bulletin, 48, 14291432 .

Wünnemann, B., K. Hartmann, N. Altmann, U. Hambach, and H. J. Pachur, 2005: Interglacial and glacial fingerprints from lake deposits in the Gobi Desert, NW China. The Climate of the Past Interglacials. Developments in Quaternary Science, Sirocko et al., Eds., Elsevier, Amsterdam, 323-347.

Xiao, J., Q. Xu, T. Nakamura, X. Yang, W. Liang, and Y. Inouchi, 2004: Holocene vegetation variation in the Daihai Lake region of north-central China: A direct indication of the Asian monsoon climatic history. Quaternary Science Reviews, 23, 1669-1679.

Xiao, J., J. Wu, B. Si, W. Liang, T. Nakamura, B. Liu, and Y. Inouchi, 2006: Holocene climate changes in the monsoon/arid transition reflected by carbon con- centration in Dahai Lake of Inner Mongolia. The Holocene, 16, 551-560.

Yancheva, G., and Coauthors, 2007: Influence of the intertropical convergence zone on the East Asia Monsoon. Nature, 445, 74-77.

Yang, X., K. T. Rost, F. Lehmkuhl, Z. Zhenda, and J. Dodson, 2004: The evolution of dry lands in northern China and in the Republic of Mongolia since the Last Glacial Maximum. Quaternary International, 118119, 69-85.

Yao, T., L. G. Thompson, Y. Shi, D. Qin, K. Jiao, Z. Yang, L. Tian, and E. M. Thompson, 1997: Climate variation since the last interglaciation recorded in the Guliya ice core. Science in China (D), 40, 662-668.

Zhu, R., Q. Liu, and M. J. Jackson, 2004: Paleoenvironmental significance of the magnetic fabrics in Chinese loess-paleosols since the last interglacial (<130 ka). Earth and Planetary Science Letters, 221, 55-69. 